\title{
The Implication of Corruption on Economic Progress of Nigeria
}

\author{
Cordelia Onyinyechi Omodero \\ Correspondence: Cordelia Onyinyechi Omodero, Department of Accounting, College of Management Sciences, \\ Michael Okpara University of Agriculture, Umudike, Umuahia, Abia State, Nigeria
}

\author{
Received: April 10, 2019 Accepted: May 24, 2019 Online Published: May 30, 2019 \\ doi:10.5539/res.v11n2p110 \\ URL: https://doi.org/10.5539/res.v11n2p110
}

\begin{abstract}
The issue of corruption is a universal challenge and has denied many emerging economies good business opportunities. This study makes use of the position of Nigeria in the country corruption ranking captured by Transparency International and the rate of corruption prevailing in the country to assess the degree of influence corruption has on economic growth of the country. The study employs secondary form of data obtained from World Bank Development Indicators and Transparency International which cover a period from 2008 to 2018. The regression result indicates that the country corruption ranking has a significant negative influence on economic growth in Nigeria while the rate of corruption prevailing in the country has a significant positive impact on economic growth in the country. The two results are significant and so the study concludes that the image of the country has been tarnished globally due to the high level of corruption in Nigeria and as internationally perceived. As a result, important investment opportunities elude the country even though the economy is growing with the high rate of corruption prevailing in the country. The study thus, recommends among others that the religious leaders and non-governmental organizations should assist in curbing the menace of corruption by inculcating moral values in the young generation who should grow up to say no to corruption and its attractions. This will go a long way to salvage the future of this great nation.
\end{abstract}

Keywords: corruption, country corruption ranking, rate of corruption, economic growth, Nigeria

JEL Classification Codes: D73, O4, O47, O55

\section{Introduction}

According to Bardhan (1997) corruption refers to the utilization of government workplace for personal benefits or individual interest which is an intricate and complicated idea (AIdt, 2003). Corruption arises as individuals use affluence to purchase power, especially where there are insufficient pecuniary prospects, and when governmental influence is used to acquire riches (Danilo, Mladen \& Dusan, 2016). Corruption takes the form of bribery and embezzlement by public office holders who are entrusted with resources to manage, but prefer to be fraudulent by manipulating information and using their public office for private aims, favoritism and extortion (Andvig \& Fjeldstad, 2001). In other words, corruption is an action that violates institutional laws and regulations by government officials using their positions for selfish interest (Jain, 2001), or the sale of government property by government workers for private gain (Shleifer \& Vishny, 1993).

According to Mehmet (2014), corruption is an indication of feeble legal framework and its possible consequences on economic growth of a nation could really be devastating. Khan (1996) submits that corruption is a conduct that strays from the official guidelines for behavior governing, the actions of someone using his or her affluence, authority, position or status in a wrong and selfish manner. Corruption is a business deal among those in the private and public sectors through which publicly owned properties are unlawfully transformed into personal belongings and be regarded as pay offs (Heidenheimer, Johnston \& LeVine, 1989). Corruption by the highest political decision makers is known as political or grand corruption. Political corruption involves pretty huge bribes paid to influence policy formulation and major contract awards tailored towards private benefits (Swaleheen, 2011). There are also bureaucratic and judicial corruption which are corrupt practices by bureaucrats and judicial officials involved in effecting prevailing rules in their daily interface with the people of a nation.

Economic growth in a country can be attributed to many variables which are both positive and negative in nature (Ertimi, Dowa, Albisht \& Oqab, 2016). World Bank (2005) defines economic growth as a quantifiable variation or increase in a nation's economy. As a matter of emphasis, World Bank (2005) maintained that economic growth is usually measured as the percentage increase in gross domestic product (GDP) or gross national product (GNP) in one fiscal year. According to Nafziger (2006) economic growth is an increase in a country's per capita output which implies that economic growth is the increase in the value of goods and services produced by an economy over a period of time. Generally, economic growth can be measured by Gross Domestic Product (GDP), Gross National Product (GNP), national income (National 
Income) and Gross National Product (GDP) per capita and Per Capita Income (PCI), thus, the nature of economic growth is to guarantee the growth of both production output and production output per capita (Thach, Duong \& Oanh, 2017).

Bardhan (1997) posits that corruption is a prehistoric challenge which policy makers and social scientists have contended with for ages. The countries with high profile of corruption usually have retarded economic growth report (Maria, Adeel \& Khalid, 2013). Lack of proper leadership, transparency and accountability have remained the principal issues with corruption in Nigeria (Adegboyega, 2017). Considering the high rate of exploitation in Nigeria, it will be worthy to query the role of Anticorruption Agencies in curbing the menace of this virus which is detrimental to real economic growth in the country. The answer provided by Meagher and Voland (2006) is that Anti-graft agencies are not enough to repudiate corruption because corrupt practices are deep rooted and endorsed with lack of proper and active legal framework and political imbalances.

The economic consequences are that corruption leads to low investment and productivity which negatively impact on economic growth. The Anti-graft agencies in Nigeria such as Economic and Financial Crimes Commission (EFCC) and Independent and Corrupt Practices Commission (ICPC) have been under pressure and keep wondering whether corruption can be eradicated in Nigeria since the high level of lootings and embezzlement are perpetrated by renowned businessmen, public office holders and government officials. However, several studies on the effect of corruption on economic growth have shown significant positive influence (Damir \& Petar, 2011; Ahmad, Ullah \& Arfeen, 2012; Huang, 2012; Peev \& Mueller, 2012) while some others studies revealed significant negative impact (Pulok, 2010; Diri, 2013; Maria et al., 2013; Nguyen, Nguyen \& Binh, 2014; Nwankwo, 2014; Trabelsi \& Trabelsi, 2014; Eritimi et al. 2016; Adegboyega, 2017; Thach et al., 2017). Based on this discrepancy, this study aims at determining the influence of corruption on Nigeria's fiscal progress.

\section{Literature Review}

\subsection{Theoretical Framework}

The theory underpinning this study is the Neoclassical Theory of economic growth advocated by Solow (1956) and Swan (1956). Solow (1956) and Swan (1956) characterized neoclassical theory which denotes that an economy can have a long term growth rate as exogenously provided from outside the economic system such as capital, technological progress and labor force. Neoclassical theory advocates that corruption influences economic growth and output (Farida \& Esfahani, 2006). Neoclassical model of economic growth clearly includes the effects of corruption on economic growth which enables researchers to incorporate corruption in their model to be able to analyze the effect of corruption on economic growth. This model supersedes the approaches of previous studies that made use of models that did not consider the inherent and potential influences of corruption on economic growth. The Neoclassical economists identified three methods to counter the international dependence model which includes: the market-friendly method, the free market technique and the new political method. Using these methods, they argued that lack of development in the emerging economies are caused primarily by corruption, followed by lack of fairness in resource allocations by the government and other undue government interventions such as imposition of wrong taxes (Meier, 2000). The counter-revolution economists believe that industrialized nations and international organizations are not the cause of the problems of the developing countries, thus, scholars such as (Bauer, 1984; Lal, 1983; Johnson, 1971; Little, 1982) considered free markets operations, removal of subsidies and public ownership as a means of achieving efficiency in the public sector. Following the Neoclassical model, the emergence of two schools of thought that are connected to the effect of corruption on economic growth are identified in this study. One of the schools of thought embraces the fact that corruption leads to public sector efficiency and has a positive influence on economic growth because approval of projects are speedily given when bribes are paid to bureaucrats (Leff, 1964; Huntington, 1968; Summer, 1977; Acemoglu \& Verdier, 1998). The second school of thought holds that corruption prevents economic growth, increases transaction costs and reduces profits in business (Gould \& Amaro-Reyes, 1983; United Nations, 1990; Murphy, 1993; Mauro, 1995; Monte \& Papagni, 2001).

\subsection{Empirical Review}

Adegboyega (2017) employed fully modified ordinary least squares (OLS) method to investigate the effect of corruption on Nigeria's economic growth using secondary data from 1982 to 2015 . The findings revealed that corruption had a negative influence on economic growth in the long run. As a result, poverty level in the country has been on the increase while investment that could lead to job opportunities continues to reduce. Thach et al. (2017) used panel data of 19 Asian countries to analyze the impact of corruption on economic growth from 2004 to 2015 using DGMM data processing technique and quantile regression. The study found evidence that corruption was a hindrance to economic growth of the Asian countries covered by the study.

Danilo et al. (2016) used panel data of countries captured by the Transparency International and World Bank Development Indicators for corruption perception index (CPI) and gross domestic product (GDP) respectively. The data covered a period from 1995 to 2011 and were divided into three period zones to indicate short time impact, medium-term 
impact and long term impact of corruption on GDP. The empirical result revealed that corruption impact on economic growth most in zone 2 period which is the medium term period. Eritimi et al. (2016) examined the impact of corruption on economic growth of 14 Organization of Islamic Cooperation (OIC) from 2003 to 2010. The study employed endogenous growth theory and economic freedom index for analysis. The findings revealed that corruption had a negative impact on economic growth of the selected OIC countries.

Mehmet (2014) used meta-analysis tool to examine the effect of corruption on per capita GDP growth from 29 primary studies. The findings revealed that the effect of corruption on per capita GDP growth was more adverse in studies that employed low-income-country data only than studies that made use of the International County Risk Guide corruption perception index. Nguyen et al. (2014) estimated the direct and indirect effects of corruption on GDP growth rate in Vietnam and generally confirmed that corruption had a negative correlation with economic growth in Vietnam. Nwankwo (2014) used granger causality and regression techniques to examine the impact of corruption on Nigeria's economic growth and found that corruption had a significant negative impact on economic growth in Nigeria. Trabelsi and Trabelsi (2014) investigated the impact of corruption on economic growth of 88 countries from 1984-2011. The study found evidence that, both high and low corruption levels could decrease economic growth.

Diri (2013) employed channel methodology to assess the effect of corruption and found that the negative effect of corruption on economic growth could be observed from the rate of political instability and low level of human capital development. Maria et al. (2013) assessed the relationship between corruption and economic growth in Pakistan from 1985-2010. The regression result indicated among others that corruption had a negative impact on per capita income in Pakistan.

Ahmad et al. (2012) studied the effect of corruption on economic growth using panel data from the International Country Risk Guide corruption index, institutional quality and political stability indices and several state variables for advanced and emerging countries. The findings revealed that corruption increases economic growth rate in an inverted U-shaped way. The Huang (2012) carried out a study on 10 Asian Countries comprising China, Indonesia, Japan, South Korea, Malaysia, the Philippines, Singapore, Taiwan, Thailand and Vietnam for a period covering 1995 to 2010 . The findings revealed that corruption had a significant positive impact on economic growth, suggesting that economic growth of these countries is a function of corruption.

Using economic freedom as proxy for corruption, Peev and Mueller (2012) assessed the relationship between democracy and the growth rate of corruption in 24 post-communist economies from 1990 to 2007. The study established that high economic freedom index emanated from democratic institutions. The findings equally revealed that economic freedom led to growth in investment which resulted to high economic growth in the countries covered by the study.

Damir \& Petar (2011) investigated the impact of corruption on economic growth in Croatia and 10 transition EU member countries. The study on Croatia covered a period from 1999 to 2009 while from 1995 to 2009 were covered for the ten transition EU member countries. The study found that the impact of corruption on economic growth takes place without a significant time delay. The implication of this finding is that the existence of corruption in these countries is such that when bribe is given, certain rules are relaxed and rooms are created for quick business transactions in the country, as a result the economy is growing with it.

Swaleheen (2011) examined the effect of corruption on the rate of economic growth using a panel data of countries fro1984 to 2007. The findings revealed that corruption had a significant effect on the growth rate of real per capita income. Pulok (2010) evaluated the impact of corruption on economic growth of Bangladesh from 1984 to 2008 using Auto-regressive Distributed Lag (ARDL) bound test method. The study found the existence of a long run relationship among corruption, GDP per capita and other factors that determine GDP over the period used for the study. The findings also revealed that corruption had a direct negative impact on per capita GDP (proxy for economic development) in Bangladesh.

\subsection{Research Gap}

Several studies have been appraised and the outcomes indicate that corruption has both negative influence on economic growth (Ahmad et al., 2012; Huang, 2012; Peev \& Mueller, 2012) as well as positive effects (Maria et al., 2013; Nwankwo, 2014; Pulok, 2016; Thach et al., 2017) among others. Damir and Petar (2011) confirmed that corruption relaxes legal restrictions in business and as a result, the economy grows with it. This current study is planned to intercept these divergent views by establishing the consequences of corruption on economic growth of Nigeria for a period covering 2008 to 2018.

\section{Methodology}

The study employed a descriptive research design which describes the kind of association existing between the independent variables and the dependent variable in a certain area of research. This choice is motivated by the fact that all 
the variables are quantitative in nature and are numerically gathered for statistical analysis. Descriptive research design allows the researcher to statistically measure and analyze data in order to draw an empirical evidence from a study. The study is on the impact of corruption on economic growth in Nigeria. The dependent variable is the annual GDP growth rate while the independent variables are the Country Corruption Ranking (CCR) and the Rate of Corruption (ROC) in Nigeria. The Corruption Perception Index (CPI) captured by the Transparency International shows that the CPI is based on a 10-point scale in which a score of 10 specifies a very slight corruption and a score of 0 shows a very corrupt government. In scoring freedom from corruption, the Index translates the raw CPI data to a scale of 0 to 100 by multiplying the CPI score by 10 . For example, if a country's raw CPI data score is 5.5, its overall freedom from corruption score is 55 (Heritage Organization, 2019). Based on this background, the ROC of corruption in Nigeria used in this study is arrived at by multiplying the Nigeria CPI data by 100 to get the Nigeria's degree of freedom from corruption. The values obtained were subtracted from 100 to arrive at the actual Rate of Corruption (ROC) in Nigeria. The data for the GDP growth rate were collected from the World Bank Development Indicators while the CPI data used before conversion to ROC were obtained from the Transparency International. All the data for the variables were collected from 2008 to 2018 and were all expressed in logarithm form for uniformity and ease of analysis.

The multi-regression analysis was carried out with the aid of e-views version 9 . The significance level is at $5 \%$ level of significance.

The model specified for the study is stated as follows:

LOGGDP $=\quad \propto+\beta_{1}($ LOGCCR $)+\beta_{2}($ LOGROC $)+\varepsilon$

Where,

$\begin{array}{lll}\text { GDP } & = & \text { Annual Growth Rate of Gross Domestic Product } \\ \mathrm{CCR} & = & \text { Country Corruption Ranking } \\ \mathrm{ROC} & = & \text { Rate of Corruption } \\ \dot{\alpha} & = & \text { Constant } \\ \beta_{1}-\beta_{2} & = & \text { Regression Coefficients } \\ \varepsilon & = & \text { Error term }\end{array}$

A Priori economic expectation:

$\beta_{1}, \beta_{2}<0$

The a priori economic expectation is that CCR and ROC should be less than zero indicating negative effect of corruption on economic growth rate in Nigeria.

\section{Data Analysis and Interpretations}

4.1 Graphical Presentation of Trend of Data

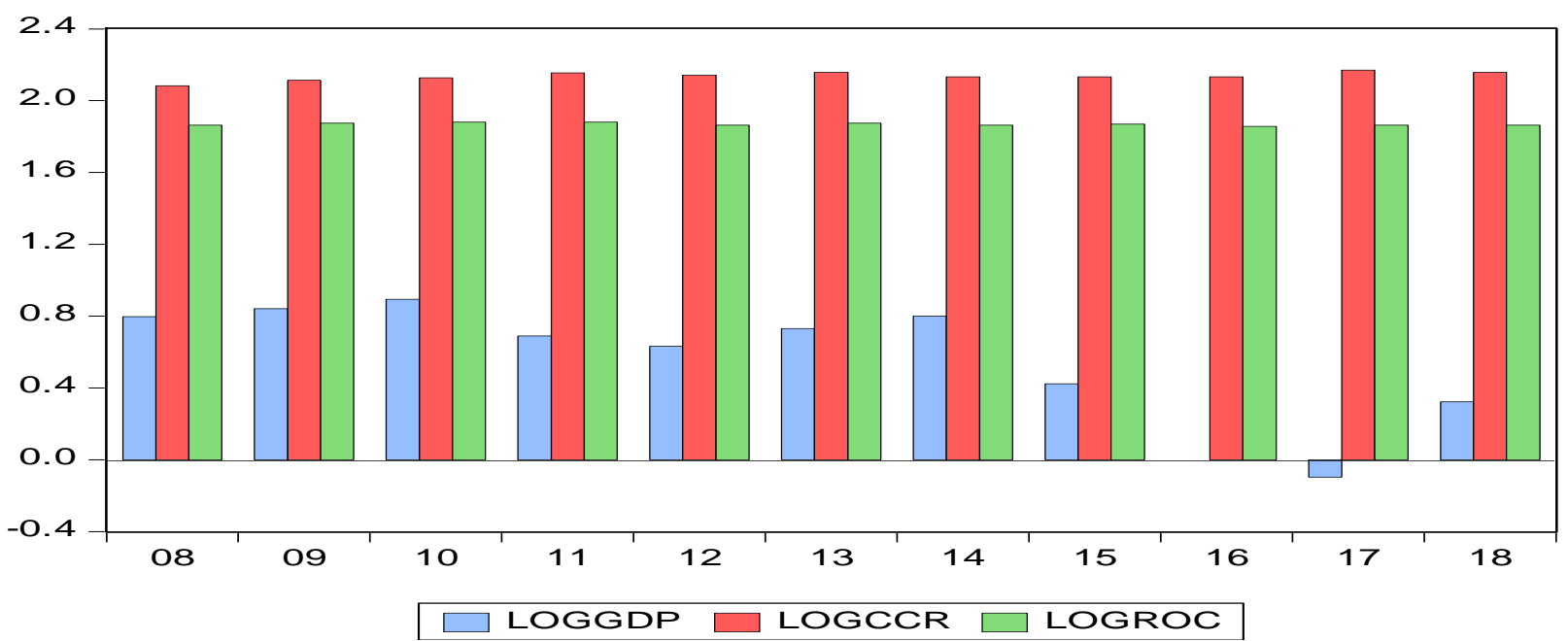

Figure 1. Trend of data from 2008-2018

Source of Data: World Bank Development Indicators and Transparency International

Figure 1 above shows the trend of the data values of the variables from 2008 to 2018. From the figure above, the rate of corruption is high in each of the years as well as the ranking of Nigeria as a corrupt country. The implication is that the 
whole economy has been integrated with corruption as though they are inseparable. A closer observation on this graph indicates that the economy is not really at its best with the scenario, however, the regression result below has a better explanation in this regard.

\subsection{Regression Result}

Table 1. Regression Result

Dependent Variable: LOGGDP

Method: Least Squares

Date: 02/21/19 Time: 17:02

Sample: 20082018

Included observations: 11

\begin{tabular}{|c|c|c|c|c|}
\hline Variable & Coefficient & Std. Error & t-Statistic & Prob. \\
\hline LOGCCR & -7.430183 & 2.956483 & -2.513183 & 0.0362 \\
\hline LOGROC & 26.95647 & 8.989903 & 2.998528 & 0.0171 \\
\hline $\mathrm{C}$ & -33.94301 & 17.60508 & -1.928024 & 0.0900 \\
\hline R-squared & 0.644278 & Mean dependent var & & 0.548477 \\
\hline Adjusted R-squared & 0.555347 & S.D. dependent var & & 0.342734 \\
\hline S.E. of regression & 0.228543 & Akaike info criterion & & 0.112816 \\
\hline Sum squared resid & 0.417855 & Schwarz criterion & & 0.221333 \\
\hline Log likelihood & 2.379511 & Hannan-Quinn criter. & & 0.044411 \\
\hline F-statistic & 7.244731 & Durbin-Watson stat & & 1.348700 \\
\hline Prob(F-statistic) & 0.016012 & & & \\
\hline
\end{tabular}

Source: Author's Computation, 2019

Table 1 above indicates the regression result of this study. From table 1 above, the $\mathrm{R}$ value is $80.3 \%$ (square root of $\mathrm{R}$-squared). This is an indication that the association between economic growth in Nigeria and corruption is very strong. In the same manner the R-squared has the value of $64.4 \%$ which implies that the rate of corruption and the position of Nigeria in the country ranking explain up to $64.4 \%$ of the changes in economic growth in Nigeria while the remaining $35.6 \%$ is attributable to other variables that are not included in the model. The Durbin-Watson is within the limit that does not give cause for concern. The value of the F-statistic is 7.244731 with the p-value of $0.01<0.05$. The p-value shows that the result is statistically significant and the model is suitable for the study. The result also signifies that the rate of corruption and the Country's position in the ranking jointly affect the economic growth of Nigeria.

The t-statistic shows the individual performance of the independent variables and the degree of influence each is having on economic growth of the country. From table 1 above, CCR t-statistic is -2.513183 while the p-value is $0.03<0.05$ level of significance. This result shows that the position of Nigeria in the ranking of corrupt countries has a significant negative influence on economic growth of Nigeria. On the contrast, ROC t-statistic is 2.998528 while the p-value is $0.01<0.05$ level of significance. This result implies that the rate of corruption in Nigeria has a significant positive impact on economic growth of the country. This result agrees with the findings of (Damir \& Petar, 2011; Ahmad, Ullah \& Arfeen, 2012; Huang, 2012; Peev \& Mueller, 2012) but conflicts with the studies of (Pulok, 2010; Diri, 2013; Maria et al., 2013; Nguyen, Nguyen \& Binh, 2014; Nwankwo, 2014; Trabelsi \& Trabelsi, 2014; Eritimi et al. 2016; Adegboyega, 2017; Thach et al., 2017) who found that corruption influences economic growth negatively.

\section{Conclusion and Recommendations}

\subsection{Conclusion}

The study examines the impact of corruption on economic growth of Nigeria using the country corruption ranking and the rate of corruption in Nigeria to assess the degree of influences corruption has on growth in the country. The significant negative impact of CCR on GDP growth rate met the a priori expectation while the ROC did not meet the economic a priori expectation. The country corruption ranking captured by Transparency International has a global implication on the economic growth of the country. It shows how the global investment community will perceive Nigeria and other countries 
in terms of investment considerations. The reason is that corruption increases the transaction costs of an investor and reduces the investment returns or profits. In this regard, a risk averse investor will not like to take such risk. Secondly, a country's global reputation when it comes to business transactions is very key in determining whether to do business in that country or not. Based on this background, the study concludes that the position of Nigeria as one of the highest corrupt countries in the world has actually affected economic growth of the country negatively. Certain technological inflows through foreign direct investments have eluded the Nigeria due to the high level of corruption in the country being viewed globally. On the contrary, the result also shows that the rate of corruption prevailing in Nigeria's economic system and in the political sphere is so pronounced that the economy is even excelling with it. This means that Nigeria is a place where bribery prevails when it comes to business. In other words, there is less regard for rules and institutional qualities, rather bribe makes businesses to move faster and the economy is growing. This is an ugly scenario and should be condemned by all standards.

\subsection{Recommendations}

- The study suggests a total overhauling of the Nigeria's legal system which has to do with good leadership in place. The need for good leadership is paramount in achieving this goal because without good governance there will be no better Nigeria.

- The efforts of the Anticorruption agencies have to be supplemented by religious leaders and non-governmental organizations who have the opportunity to teach the citizens the need for moral values. When moral values are inculcated in people especially the young generation, it goes a long way to help them resist the attractions and pressures of corrupt practices emanating from their peers and associates.

- The government should encourage people to insist on getting things done in the right manner, that is following due process. Citizens should shun bribe and stand on their right to obtain whatever they need for their businesses, studies and other transactions as long as the official requirements are met.

- Whistle blowing is highly recommended and should be strongly encouraged, that is, citizens should be adequately supported to report all corrupt practices in all public offices without putting their lives at risk.

\section{Acknowledgement}

The author is grateful to the anonymous reviewers and editors of Review of European Studies for their valuable contributions and helpful remarks that improved the quality of this paper.

\section{References}

Acemoglu, D., \& Verdier, T. (1998). Property Rights, Corruption and the Allocation of Talent: A General Equilibrium Approach. Economic Journal, 108(45), 1381-1403. https://doi.org/10.1111/1468-0297.00347

Adegboyega, R. (2017). Corruption and economic growth in Nigeria: A co-integration (FM-OLS) Approach. Annals of the University of Petrosani Economics, 17(1), 5-18.

Ahmad, E., Ullah, M. A., \& Arfeen, M. I. (2012). Does corruption affect economic growth? Latin American Journal of Economics, 49(2), 277-305. https://doi.org/10.7764/LAJE.49.2.277

Aidt, T. (2003). Economic analysis of corruption: A survey. The Economic Journal, 113, 632-652. https://doi.org/10.1046/j.0013-0133.2003.00171.x

Andvig, J. C., \& Fjeldstad, O. (2001). Corruption: a review of contemporary research (CMI Report R 2001:7). Bergen: Chr. Michelsen Institute. Retrieved on March 15, $2019 \quad$ from http://www.cmi.no/publications/file/?861=corruption-a-review-of-contemporary-research

Bardhan, P. (1997). Corruption and development: A review of issues. Journal of Economic Literature, 35, $1320-1346$.

Bauer, P. T. (1984). Reality and rhetoric: Studies in the economics of development. London: Weidenfield \& Nicolson.

Damir, P., \& Petar, C. (2011). Corruption and economic growth in Croatia. Oeconomica Jadertina, 2/2011. UDK: 330.35:343.352>(497.5):111.

Danilo, L., Mladen, R., \& Dusan, D. (2016). Causality between corruption and the level of GDP. Economic ResearchEkonomska Istrazivanja, 29(1), 360-379. https://doi.org/10.1080/1331677X.2016.1169701

Dridi, M. (2013). Corruption and economic growth: The transmission channels. Journal of Business Studies Quarterly, 4(4), 121-152.

Eritimi, B. E., Dowa, A., Albisht, E. M., \& Oqab, B. A. (2016). The impact of corruption on Economic growth in OIC Countries. International Journal of Economics and Finance, 8(9), 91-103. https://doi.org/10.5539/ijef.v8n9p91

Farida, M., \& Esfahani, F. (2006). Corruption and economic growth in Lebanon. Australian Agricultural and Resource 
Economics Society 52nd Annual Conference. http:// purl.umn.edu/6043

Gould, D. J., \& Amaro-Reyes, J. A. (1983). The effects of corruption on administrative Performance: Illustrations from developing countries. World Bank Staff Working paper, No. 580.

Heidenheimer, A. J., Johnston, M., \& LeVine, V. T. (Eds.). (1989). Political corruption. A Handbook. New Brunswick: Transaction Publishers.

Heritage Organization. (2019). Government integrity. Retrieved from: https//www.heritage.org/Index/freedom-from-corruption, on January 29, 2019

Huang, C. J. (2012). Corruption, economic growth, and income inequality: Evidence from ten Countries in Asia. World Academy of Science, Engineering and Technology, 66.

Huntington, S. P. (1968). Political Order in Changing Societies. New Heaven: Yale University Press.

Jain, A. (2001). Corruption a review. Journal of Economic Surveys, 15, 71-121. https://doi.org/10.1111/1467-6419.00133

Johnson, H. (1971). A word to the third world: A Western economist's frank advice, Encounter, 37, 3-10. https://doi.org/10.1016/B978-0-08-016325-3.50011-9

Khan, M. (1996). A typology of corrupt transactions in developing countries. IDS Bulletin, Liberalization and the New Corruption, 27(2), 12-21. https://doi.org/10.1111/j.1759-5436.1996.mp27002003.x

Lal, D. (1983). The poverty of development economics. London: Institute of Economic Affairs.

Leff, N. H. (1964). Economic Development through Bureaucratic Corruption. American Behavioral Scientist, 8(3), 8-14. https://doi.org/10.1177/000276426400800303

Little, I. M. D. (1982). Economic development: Theory, policy, and international relations. New York: Basic Books.

Maria, A., Adeel, A., \& Khalid, Z. (2013). The relationship between corruption and economic Growth in Pakistan looking beyond the incumbent. Oeconomics of Knowledge, 5(3), 16-45.

Mauro, P. (1995). Corruption and Growth. Quarterly Journal of Economics, 109(2), 681-712. https://doi.org/10.2307/2946696

Meagher, P., \& Voland, C. (2006). Anticorruption program brief. Anticorruption Agencies (ACAs). Office of Democracy and Governance. http://pdf.usaid.gov/pdf_docs/ PNADM208.pdf

Mehmet, U. (2014). Corruption is direct effects on per capita income growth: A meta-analysis. Journal of Economic Surveys, 28(3), 472-490. https://doi.org/10.1111/joes.12035

Meier, G. M. (2000). The old generation of development economists and the new, in G.M. Meier\& J.E. Stiglitz (Eds.). Frontiers of development economics: The future in perspective (pp. 13-50) Washington, D.C.: World Bank/Oxford University Press. https://doi.org/10.1596/0-1952-1592-3

Monte, A. D., \& Erasmo, P. (2001) Public Expenditure, Corruption, and Economic Growth: The Case of Italy. European Journal of Political Economy, 17(1), 1-16. https://doi.org/10.1016/S0176-2680(00)00025-2

Murphy, K. M. (1993). Why is Rent-Seeking So Costly to Growth? American Economic Review, 83(2), 409-414.

Nafziger, E. W. (2006). From Seers to Sen: The Meaning of Economic Development. Research Paper 2006/20, UNU WIDER, Helsinki. Retrieved on March 15, 2019 from: https://www.wider.unu.edu/sites/default/files/r p2006-20.pdf.

Nguyen, N. A., Nguyen, N. M., \& Binh, T. N. (2014). Corruption and economic growth, with a focus On Vietnam. Munich Personal RePec Archives. Available at: https://mpra.ub.uni-muenchen.de/84728/

Nwankwo, O. (2014). Impact of corruption on economic growth in Nigeria. Mediterranean Journal of Social Sciences, 5(6), 41-46. https://doi.org/10.5901/mjss.2014.v5n6p41

Peev, E., \& Mueller, D. C. (2012). Democracy, economic freedom and growth in Transition Economies. Kyklos, 65(3), 371-407. https://doi.org/10.1111/j.1467-6435.2012.00543.x

Pulok, M. H. (2010). The impact of corruption on economic development of Bangladesh: Evidence On the basis of an extended Solow Model. Munich Personal RePEc Archive. Available At: https://mpra.ub.uni-muenchen.de/28755/

Shleifer, A., \& Vishny, R. W. (1993). Corruption. Quarterly Journal of Economics, 108, 599-618. https://doi.org/10.2307/2118402

Solow, R. (1956). A Contribution to the Theory of Economic Growth. Quaterly Journal of Economics, 70(1), 65-85. https://doi.org/10.2307/1884513 
Summers. (1977). Speech to the Summit of Eight, Denver.

Swaleheen, M. (2011). Economic growth with endogenous corruption: An empirical study. Public Choice, 146(1-2), 23-41. https://doi.org/10.1007/s11127-009-9581-1

Swan, T. (1956). Economic Growth and Capital Accumulation. Econ. Record, (32), 334-361. https://doi.org/10.1111/j.1475-4932.1956.tb00434.x

Thach, N. N., Duong, M. B., \& Oanh, T. T. K. (2017). Effects of corruption on economic growth-Empirical study of Asia Countries. Imperial Journal of Interdisciplinary Research, 3(7), 791-804.

Trabelsi, M. A., \& Trabelsi, H. (2014). At what level of corruption does economic growth Decrease? Munich Personal RePec Archive. Available on at: https://mpra.ub.uni-muechen.de/81279/

United Nations. (1990). Corruption in Government. New York: United Nations.

World Bank. (2005). Economic Growth in the 1990s: Learning from a Decade of Reform. Washington DC: World Bank.

\section{Copyrights}

Copyright for this article is retained by the author(s), with first publication rights granted to the journal.

This is an open-access article distributed under the terms and conditions of the Creative Commons Attribution license (http://creativecommons.org/licenses/by/4.0/). 